\title{
Carbon stocks in a tropical dry forest in Brazil ${ }^{1}$
}

\author{
Estoque de carbono em uma floresta tropical seca no Brasil
}

\author{
Lécio Resende Pereira Júnior 2*, Eunice Maia de Andrade³ ${ }^{3}$ Helba Araújo de Queiroz Palácio ${ }^{4}$, Poliana Costa \\ Lemos Raymer 5 , Jacques Carvalho Ribeiro Filho ${ }^{4}$ e Francisco Jairo Soares Pereira ${ }^{3}$
}

\begin{abstract}
The dry forests are the type most widely distributed vegetation in the tropics, and studies aimed at quantifying the carbon stock in these forests are important for it to be quantified their participation as mitigating the effects of climate change. With that in mind, the aim of this research was to quantify the carbon stocks in the woody, herbaceous, litter and root components of a patch of dry tropical forest, with 30 years of regeneration in Iguatu-CE, Brazil. Initially the vegetation was inventoried by means of a floristic and phytosociological survey of the woody component in a 1 ha area which had been under conservation. The biomass was then estimated employing allometric equations, and the stored carbon was quantified. Stocks of carbon in the litter and the herbaceous plants were determined by monitoring their biomass over 24 months, with subsequent conversion into carbon. Carbon stocks in the roots were estimated as the product of their biomass and carbon concentrations, for this were collected 20 samples at a depth of up to $30 \mathrm{~cm}$ deep in the dry and rainy season. It was found that the carbon content varies with the chamber and evaluated by adding carbon stored in woody compartments $\left(19,27 \mathrm{t} \mathrm{ha}^{-1}\right)$ litter $\left(2.62 \mathrm{t} \mathrm{ha}^{-1}\right)$ plants herbaceous $\left(0.57 \mathrm{tha}^{-1}\right)$ and roots $\left(4.73 \mathrm{tha}^{-1}\right)$, the total carbon stored in the dry tropical forest with 30 years of regeneration is around $27.19 \mathrm{t} \mathrm{C} \mathrm{ha}^{-1}$. The dry tropical forest acts effectively in reducing $\mathrm{CO}_{2}$ atmospheric.
\end{abstract}

Key words: Semi-arid. Caatinga. Biomass.

RESUMO - As florestas secas são amplamente distribuídas nos trópicos, e estudos que visam quantificar o estoque de carbono nessas florestas são importantes para que possa ser quantificada sua participação como mitigadora dos efeitos das mudanças climáticas. Nesse sentido, objetivou-se com essa pesquisa quantificar o estoque de carbono nos componentes: arbustivoarbóreo, herbáceo, serrapilheira e raízes em um fragmento de floresta tropical seca, com 30 anos de regeneração, no município de Iguatú-CE. Inicialmente, realizou-se o inventário da vegetação, através de um levantamento florístico e fitossociológico do componente arbustivo-arbóreo. Posteriormente, estimou-se sua biomassa, empregando-se equações alométricas; em sequencia foi quantificado o carbono estocado. Já o estoque de carbono contido na serrapilheira e nas plantas herbáceas foi determinado através do monitoramento de suas biomassas, durante 24 meses, com posterior conversão dessas para carbono. O estoque de carbono contido nas raízes foi estimado através do produto entre suas biomassas e a concentração de carbono, para isso foram coletadas 20 amostras na camada de até $30 \mathrm{~cm}$ de profundidade no período seco e chuvoso, totalizando 40 amostras por ano. O teor de carbono varia de acordo com o compartimento avaliado, e somando-se o carbono estocado nos compartimentos arbustivo-arbóreo $\left(19,27 \mathrm{t} \mathrm{ha}^{-1}\right)$, serrapilheira $\left(2,62 \mathrm{t} \mathrm{ha}^{-1}\right)$, plantas herbáceas $\left(0,57 \mathrm{t} \mathrm{ha}^{-1}\right)$ e raízes $\left(4,73 \mathrm{t} \mathrm{ha}^{-1}\right)$, o carbono total estocado na floresta tropical seca com 30 anos de regeneração está em torno de 27,19 t C ha-1. Isso evidencia, portanto, a contribuição efetiva da floresta tropical seca na diminuição do $\mathrm{CO}_{2}$ atmosférico.

Palavras-chave: Semiárido. Caatinga. Biomasa.

\footnotetext{
DOI: $10.5935 / 1806-6690.20160004$

* Autor para correspondência

${ }^{1}$ Recebido para publicação em 14/09/2014; aprovado em 29/07/2015

Parte da Tese do primeiro autor apresentada no Programa de Pós-Graduação em Ecologia e Recursos Naturais da Universidade Federal do Ceará/UFC ${ }^{2}$ Programa de Pós-Graduação em Ecologia e Recursos Naturais, Centro de Ciências/UFC, Campus do Pici, Caixa Postal: 6021, Bloco: 902, Fortaleza-CE, Brasil, 60.455-970, leciojunior@ hotmail.com

${ }^{3}$ Departamento de Engenharia Agrícola, Centro de Ciências Agrárias, Universidade Federal do Ceará, Fortaleza-CE, Brasil, eandrade@ufc.br, jairoagronomia@hotmail.com

${ }^{4}$ Instituto Federal de Educação, Ciências e Tecnologia do Ceará/IFCE, Campus Iguatu-CE, Brasil, helbaraujo23@yahoo.com.br, jacquesfilho1@hotmail.com

${ }^{5}$ Departamento de Biologia da Universidade de Boston /BU, Boston-MA, polianaclemos@gmail.com
} 


\section{INTRODUCTION}

Dry forests are the most widely distributed type of vegetation in the tropics, covering $42 \%$ of all tropical vegetation (SANTOS et al., 2011). However, they have not been in the forefront of carbon credit trading, mainly due to a lesser accumulation of biomass compared to moist forests (SKUTSCH; LIBASSE, 2010). Yet, while dry forests usually have lower biomass than moist forests, their extensive coverage makes them a significant compartment of terrestrial carbon (GLENDAY, 2008).

An approach directed at the quantification of the biomass and carbon in tropical forests, and aimed at understanding the potential for carbon stock in these forests, is of considerable importance, given the threat of a worsening of the established environmental crisis, a reflection of the anthropogenic pressures being exerted (MOHANRAJ et al., 2011).

In several works, quantitative data can be found of carbon stock in several forest formations, such as humid tropical (NGO et al., 2013), woody savannas (PAIVA; REZENDE; PEREIRA, 2011; REZENDE et al., 2006) and temperate forests (THURNER et al., 2014). However, the few studies related to the quantification of carbon stocks in dry forests, compromises understanding of the process of $\mathrm{CO}_{2}$ conversion in these ecosystems, underestimating its importance as a regulator of the carbon cycle.

With this in mind, the aim of this research was to quantify the carbon stock in a fragment of tropical dry forest, including its components: woody, herbaceous, litter and roots, and provide an estimate of the potential for carbon storage of the ecosystem.

\section{MATERIAL AND METHODS}

\section{Study area}

The study was carried out from May 2012 to May 2014, at the Federal Institute for Science and Technology of Ceará (IFCE), located in the town of Iguatu, in the state of Ceará, Brazil, in a fragment of tropical dry forest of homogeneous physiognomy, under regeneration for about 30 years after a period of deforestation and conventional agricultural cultivation. It is located at $6^{\circ} 23$ ' $38^{\prime \prime} \mathrm{S}$ and $39^{\circ} 15^{\prime} 21$ " W.

According to the Köppen classification, the climate in the region is of type BSw'h' (hot semi-arid, with autumn rains and average monthly temperatures always above $18{ }^{\circ} \mathrm{C}$ ). The average annual rainfall is $867 \pm 304 \mathrm{~mm} \mathrm{yr}^{-1}$. Average evapotranspiration is $1,988 \mathrm{~mm} \mathrm{yr}^{-1}$, with temperatures between 20.3 and $31.7{ }^{\circ} \mathrm{C}$ (PALÁCIO, 2011).

\section{Phytosociological and floristic survey}

The area was divided into contiguous plots, 10 $\mathrm{x} 10 \mathrm{~m}$ in size, giving 100 plots, each of $100 \mathrm{~m}^{2}$. This methodology is commonly used for surveys in dry forests in the Brazilian semi-arid region (PEREIRA JUNIOR; ANDRADE; ARAÚJO, 2012).

Live individuals of woody species with a circumference at the base (CB) of $\geq 9 \mathrm{~cm}$ and a height (h) of $>100 \mathrm{~cm}$ were quantified for each plot, (PEREIRA JUNIOR; ANDRADE; ARAÚJO, 2012). The height was measured with the aid of a telescopic rule, and the circumference of the stem was measured $10 \mathrm{~cm}$ from ground level using a tape measure. From the values obtained for the circumference, the diameter of each individual was calculated by equation 1 :

$$
D=\frac{C B}{\pi}
$$

where: $\mathrm{D}=$ diameter in $\mathrm{cm} ; \mathrm{CB}=$ circumference at the base in $\mathrm{cm}$.

For species identification and quantification, botanical material was collected by selecting three samples per species. The exsiccatae are kept in the Jaime Coelho de Morais Herbarium at the Federal University of Paraíba, at the level of family, genus and species.

\section{Stocks of woody-component biomass}

Of the species identified in the area, four had their biomass determined by specific allometric equations, for the remaining species, due to the absence of specific equations, the general equation was used (Table 1).

\section{Stocks of litter biomass}

The stocks of biomass in the litter were calculated by studying their accumulation in the experimental area. Samples were collected monthly for 24 months, with 20 replications, using a hollow frame of $0.25 \mathrm{~m}^{2}$, which was thrown at random into the plots (LOPES et al., 2009). The collected litter was dried in an oven at $60{ }^{\circ} \mathrm{C}$ to constant weight and weighed shortly after on a precision balance (SOUTO, 2006). Stocks in the area were determined monthly by multiplying the average for the litter biomass found in each $0.25 \mathrm{~m}^{2}$ by the total area $\left(10,000 \mathrm{~m}^{2}\right)$.

\section{Stocks of herbaceous-component biomass}

Twenty samples were collected monthly (24 months), from inside the plots. For this, a metal frame of $0.25 \mathrm{~m}^{2}$ was thrown randomly, and all the herbaceous material inside was collected. The samples were dried 
Table 1 - Allometric equations developed for species of the caatinga. All for $\mathrm{p}<0.01$

\begin{tabular}{lcc}
\hline \multicolumn{1}{c}{ Species } & Equation & $\mathrm{R}^{2}$ \\
\hline Aspidosperma pyrifolium & $\mathrm{B}=0.2455^{*} \mathrm{DB}^{1.7726}$ & 0.9265 \\
Croton sonderianus & $\mathrm{B}=0.1482^{*} \mathrm{DB}^{1.8741}$ & 0.8266 \\
Jatropha mollissima & $\mathrm{B}=0.0689^{2} \mathrm{DB}^{2.0557}$ & 0.7668 \\
Myracrodruon urundeuva & $\mathrm{B}=0.0596 * \mathrm{DB}^{2.4878}$ & 0.9739 \\
General equation & $\mathrm{B}=0.0292^{*}(\mathrm{DB} * \mathrm{H})^{1.6371}$ & 0.9382 \\
\hline
\end{tabular}

B = Biomass (kg); DB = Diameter at base (cm); H = Height (m) (SAMPAIO; SILVA, 2005)

in an air circulation oven at $60{ }^{\circ} \mathrm{C}$ to constant weight, and the material then weighed on an analytical balance. Stocks of herbaceous biomass were determined monthly by multiplying the average for herbaceous biomass found in each $0.25 \mathrm{~m}^{2}$ by the total area $\left(10,000 \mathrm{~m}^{2}\right)$.

\section{Stocks of root biomass}

To quantify root biomass, the root $\mathrm{x}$ shoot ratio was used (MOKANY et al., 2006); this states that tropical dry forests with a shoot biomass exceeding $20 \mathrm{t} \mathrm{ha}^{-1}$ have a root biomass corresponding to $27.5 \%$ of that seen on the surface.

Variations in root biomass were also assessed during the rainy and dry seasons; for this, the biomass of the fine, medium and coarse roots was quantified for the two years of the study, following a methodology adapted from Navroski et al. (2010) and Paiva, Rezende and Pereira (2011).

To quantify the fine-root biomass $(\phi<2 \mathrm{~mm})$, 20 sampling points were randomly selected, spaced a minimum of $10 \mathrm{~m}$ apart and at a distance of $2 \mathrm{~m}$ from the nearest individual. At each point, soil samples were collected in the 0.0 to $30.0 \mathrm{~cm}$ layer, with the aid of an iron cylinder, $100 \mathrm{~cm}$ in length and of known volume. To quantify the medium roots $(2<\phi<10 \mathrm{~mm})$ and coarse roots $(\phi>10 \mathrm{~mm})$, ten trenches, each $0.5 \times 0.5 \mathrm{~m}$ and $0.3 \mathrm{~m}$ deep, were opened and any roots found were collected.

The samples were packed and taken to the soil-analysis laboratory of IFCE, where they were separated, washed in running water and placed in an oven at $60{ }^{\circ} \mathrm{C}$ until reaching constant weight. The stocks for each period were estimated by multiplying the average for root biomass in each $\mathrm{m}^{2}$ by the total area $\left(10,000 \mathrm{~m}^{2}\right)$.

\section{Stocks of carbon}

To quantify the stocks of carbon, the carbon content was determined as per a methodology adapted from Vieira et al. (2009), and considering the ratio of biomass to carbon content as determined for each compartment under evaluation (woody, herbaceous, litter and roots).

To determine the carbon content of the woody compartment, core samples of species with at least six individuals (ind) in the area were collected with the help of a Presley auger; in this way 10 samples were collected per species (2/ind), to make up a composite sample for each species. To determine the carbon content of the herbaceous species and the litter, monthly collections of biomass were made, resulting in a composite sample for each compartment; whereas with the roots, the carbon content for each of the three diameter classes was determined, and the average of the three classes then calculated. This average was used to determine the stocks of carbon in the root $\mathrm{x}$ shoot ratio.

Carbon content was measured by the dry combustion method, employing the LECO Model C-144 elemental analyser, by means of three replications of the composite samples. Eighteen composite samples were analysed (18 species) from the woody compartment, one from the litter compartment, one from the herbaceous plants, and 3 from the root compartment (fine, medium and coarse). The data were subjected to variance analysis and the means were then compared by Tukey's test.

\section{RESULTS AND DISCUSSION}

\section{Flora and phytosociology}

In the floristic and phytosociological survey, 3,738 individuals/ha (4,922 stems) were sampled, distributed over 12 families, 21 genera and 22 species.

The most abundant species were Croton sonderianus, Mimosa caesalpiniifolia, Aspidosperma pyrifolium, Combretum leprosum and Bauhinia cheilantha (Table 1), which represent $81.54 \%$ of the total density of individuals, demonstrating the dominance of one species group over another, typical behaviour of forests in a stage of regeneration. Pereira Júnior, Andrade e Araújo (2012) 
also observed similar behaviour when studying a dry forest preserved for 30 years in the town of Monteiro, in the state of Paraíba, Brazil.

The number of identified species (22) is considered low when compared to that found by Alcoforado Filho, Sampaio and Rodal (2003), who found 96 species when evaluating a tropical dry forest in Caruarú, in the state of Pernambuco. The low number of species found in the experimental area is related to the stage of regeneration of the forest fragment, reflecting the period of farming to which the area was submitted.

The density of quantified plants $\left(3,805\right.$ ind ha $\left.^{-1}\right)$ was similar to that found by Santana and Souto (2006), 4,080 ind $\mathrm{ha}^{-1}$ in a tropical dry forest preserved for 33 years in Serra Negra do Norte, in the state of Rio Grande do Norte. It therefore appears possible that areas of tropical dry forest under regeneration display similar plant densities over time.

\section{Carbon content}

Even in a semi-arid environment, where climatic conditions impose greater specific density on plant tissue due to slower growth (VIEIRA et al., 2009), the results show (Table 2) that the carbon content found in the woody compartment is inferior to that proposed by the Intergovernmental Panel on Climate Change (IPCC) (2007), which estimates that $50 \%$ of the biomass of all forest fragments can be considered as carbon.

Table 2 - Average carbon content of compartments of a tropical dry forest under regeneration

\begin{tabular}{lc}
\hline \multicolumn{1}{c}{ Compartment } & Average carbon content $(\%)$ \\
\hline Woody & $44.53 \pm 1.88 \mathrm{ab}$ \\
Litter & $42.76 \pm 0.77 \mathrm{bc}$ \\
Herbaceous plants & $38.17 \pm 0.25 \mathrm{~d}$ \\
Fine roots & $30.87 \pm 0.76 \mathrm{e}$ \\
Medium roots & $43.50 \pm 0.13 \mathrm{abc}$ \\
Coarse roots & $45.11 \pm 0.24 \mathrm{a}$ \\
\hline
\end{tabular}

Mean values compared by Tukey's test at $0.01 \%$ probability

If the IPCC index were adopted in this study, the stock of carbon in the dry forest under evaluation could possibly be overestimated, however, as the samples used to determine the carbon content were taken from trees of a secondary forest, research would be needed in forests with a greater period of conservation to confirm whether or not the $50 \%$ percentage adjustment proposed by the IPCC is necessary. It is therefore clear that it is important to determine the carbon content of a tropical dry forest, so as to arrive at a definition of a suitable percentage to be used in estimating the stock of carbon in these forests.

Furthermore, it can be seen that in the woody compartment the carbon content varied between species, as evidenced by the standard deviation (1.88). Thus, an important inference is that the carbon content of a fragment of a tropical dry forest may vary according to the species present in the area or the period of conservation. However, the low variation here shows that the content found is still much lower than that predicted by the IPCC.

The fine roots show a lower carbon content than the medium and coarse roots; this result is due to the lower density of the material, since the faster the growth, the less dense this becomes, and the lower the carbon content. The same applies to the herbaceous component, which had a lower carbon content due to its rapid growth, and as a result, lower density. Vieira et al. (2009) corroborate this assertion, reaching the same conclusion in a study that evaluates the carbon content of species at different densities.

The carbon content of the medium and coarse roots showed no significant difference when compared to the woody compartment (Table 2). As the roots in a tropical dry forest account for about $27 \%$ to $56 \%$ of tree biomass (MOKANY et al., 2006), they account for a large volume of underground stocks of biomass, with quantification of the carbon content being important for greater precision in estimating stocks.

\section{Stocks of carbon in the woody component}

In Table 3 can be seen biomass and carbon stocks for individuals of the woody plants present in the area under evaluation.

Table 3 - Stocks of biomass and carbon in tropical dry forest

\begin{tabular}{ccc}
\hline $\begin{array}{c}\text { Stored biomass } \\
\left(\mathrm{t} \mathrm{ha}^{-1}\right)\end{array}$ & $\begin{array}{c}\text { Carbon content } \\
(\%)\end{array}$ & $\begin{array}{c}\text { Carbon stocks } \\
\left(\mathrm{t} \mathrm{ha}^{-1}\right)\end{array}$ \\
\hline 43.28 & $44.53^{*}$ & 19.27 \\
& $50.00^{* *}$ & 21.64 \\
\hline
\end{tabular}

* Calculated carbon content; **Carbon content used by the IPCC (2007)

The value found was similar to that obtained by Skutsch and Libasse (2010), who when studying a dry forest in Africa, found up to 19.1 tonnes of carbon 
per hectare $\left(\mathrm{t} \mathrm{C} \mathrm{ha}^{-1}\right)$, values which are lower than those obtained by Aguiar et al. (2014) in a study evaluating an area of dry forest in Brazil preserved for over 50 years, where they found $67.3 \mathrm{t} \mathrm{C} \mathrm{ha}^{-1}$.

Dry forests can stock around 20 to $150 \mathrm{t} \mathrm{C} \mathrm{ha}^{-1}$ (TIESSEN et al., 1998). And among various other factors, the stage of conservation of the forest can considerably influence this stock (KOSMAS; DANALATOS; GERONTIDIS, 2000). This becomes clearer when comparing stocks of carbon in areas of forest with different periods of regeneration, as obtained by Tiessen et al. (1998), where a dry forest with over 50 years of conservation, presented a stock 3 times higher than that seen in this study for the same region $\left(19.4 \mathrm{t} \mathrm{C} \mathrm{ha}^{-1}\right)$.

When compared to the carbon stocks of the Brazilian cerrado, which has a physiognomy of dense forest, the dry forest being evaluated showed greater stocks than those identified by Rezende et al. (2006) and Paiva, Rezende e Pereira (2011), which varied between 4.93 and $13.27 \mathrm{t} \mathrm{C} \mathrm{ha}^{-1}$.

The results show that the woody component of a tropical dry forest acts effectively in mitigating global warming, since with an area of $201.4 \mathrm{~km}^{2}$ in Brazil covered with native forest (BRASIL, 2015), and a fixation of $19.27 \mathrm{t} \mathrm{ha}^{-1}$, a stock of approximately 388,000 tonnes of carbon is possible. As a result, the importance of the conservation of forest fragments of native tropical dry forests becomes clear, and also the importance of maintaining any areas under regeneration.

\section{Stocks of carbon in the litter}

Figure 1 shows the stocks of carbon in the litter, with an annual average that varies from 2.54 to $2.62 \mathrm{t} \mathrm{C}$ $\mathrm{ha}^{-1}$. This is a similar value to that found by Mohanraj, Saravanan and Dhanakumar (2011) in a dry forest in India, with a stock of up to $2.54 \mathrm{t} \mathrm{C} \mathrm{ha}^{-1}$, and greater than that proposed by Tiessen et al. (1998) of 1.38 to $1.84 \mathrm{t} \mathrm{C} \mathrm{ha}^{-1} \mathrm{yr}^{-1}$ (equivalent to $3-4 \mathrm{t} \mathrm{ha}^{-1} \mathrm{yr}^{-1}$ of biomass) in a tropical dry forest.

Despite the rainy season in the Brazilian semiarid region only being distributed over a few months, litter accumulated on the ground throughout the year. This was due to the high volume deposited and the low mobility of the litter in the area. It can be said therefore, that the litter also acts as a carbon sink, and in the case of the vegetation under evaluation, this stock showed no significant differences for the years being assessed (Figure 1).

The increase in carbon accumulation from the litter in July 2012 is related to water stress; the fall of litter, especially of leaves, being more significant, and considered a strategy by the plants of this biome to minimise water loss through high leaf transpiration. A similar response was seen in the second year of the evaluation (November 2013), however, the deposition of litter did not occur immediately after the end of the rainy season, it occurred due to the influence of the shortest period of drought in the second year in relation to the first, corroborating a study by Souto (2006) in a dry forest in Brazil.

Figure 1 - Stocks of carbon in the litter, and rainfall in a tropical dry forest

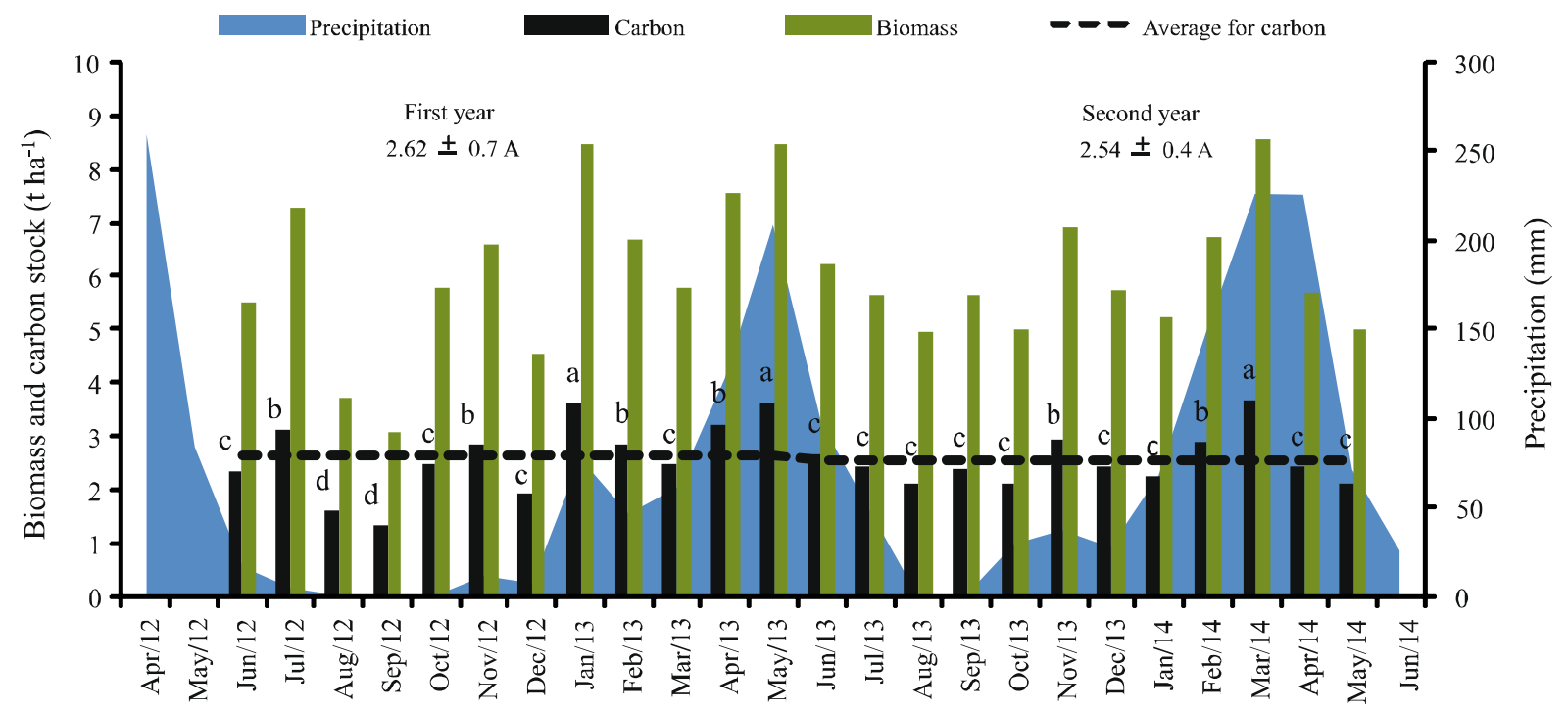

Duration 
The greatest accumulation of carbon took place in January and May 2013, and in March 2014, on the occasion of a peak in rainfall, which may be explained by the addition of litter from the herbaceous layer deposited on the soil before or during the same months as the peaks in precipitation (Figure 2), and which was added to the litter from the woody layer.

The lesser amounts of carbon stored in the soil in the second year of the evaluation, from June 2013 to January 2014, are related to the higher rate of decomposition of the litter due to an increase in the soil moisture from the high rainfall during that period. A response also verified by Santana (2005) when evaluating an area of tropical dry forest in Rio Grande do Norte.

\section{Stocks of carbon in the herbaceous component}

The average values for carbon stored per year (0.54 and $0.57 \mathrm{t} \mathrm{C} \mathrm{ha}^{-1}$ ) showed no significant difference (Figure 2), they were however lower than those observed by Glenday (2008) in a dry forest in Kenya $\left(1.8 \mathrm{t} \mathrm{C} \mathrm{ha}^{-1}\right)$.

At the end of the rainy season in 2012 (July), there was an increase in herbaceous biomass and consequently of the carbon stored in this sink (Figure 2). The fall of the leaves of the woody species, driven by drought, made possible not only a higher incidence of sunlight on the ground, but also the conservation of the soil moisture, thereby favouring the growth and development of the herbaceous layer. This response remains high in the following month (August 2012), demonstrating how the herbaceous component of tropical dry forests responds to such variations in the availability of water and light, with a view to completing its growth cycle. In the second year of the evaluation, as the dry period was shorter, this response was less clear. The variation in biomass of the herbaceous extract has been explained by Reis et al. (2006), who pointed to the existence of at least two models of population dynamics in a herbaceous community of a tropical dry forest, one not depending on seasonality and the other inconsistent, and dependent on that same seasonality. The data obtained here corroborate the assertion made by the above-mentioned authors, since the herbaceous community being evaluated presented a variable population dynamic due to climate and an ephemeral life cycle, which is characterised by seed being deposited on the soil at the end of each cycle, together with drastic reductions in moisture and population during the dry season.

It was seen that in the dry season (between September and October 2012), there was a decrease in the biomass of the herbaceous layer. With the increase in rainfall in January 2013, there was an increase in biomass shortly afterwards; the woody component issued leaves, reducing the incidence of light and increasing the competition for water with the herbaceous, sub-woody component, reflecting in a decrease in biomass in February and March 2013, this being more evident in May 2013, when there was a peak in precipitation.

Despite this variation in the herbaceous layer, a pattern to the biomass can be seen regardless of the weather conditions in the years under evaluation. It can

Figure 2 - Biomass production and carbon stocks in the herbaceous component of tropical dry forest

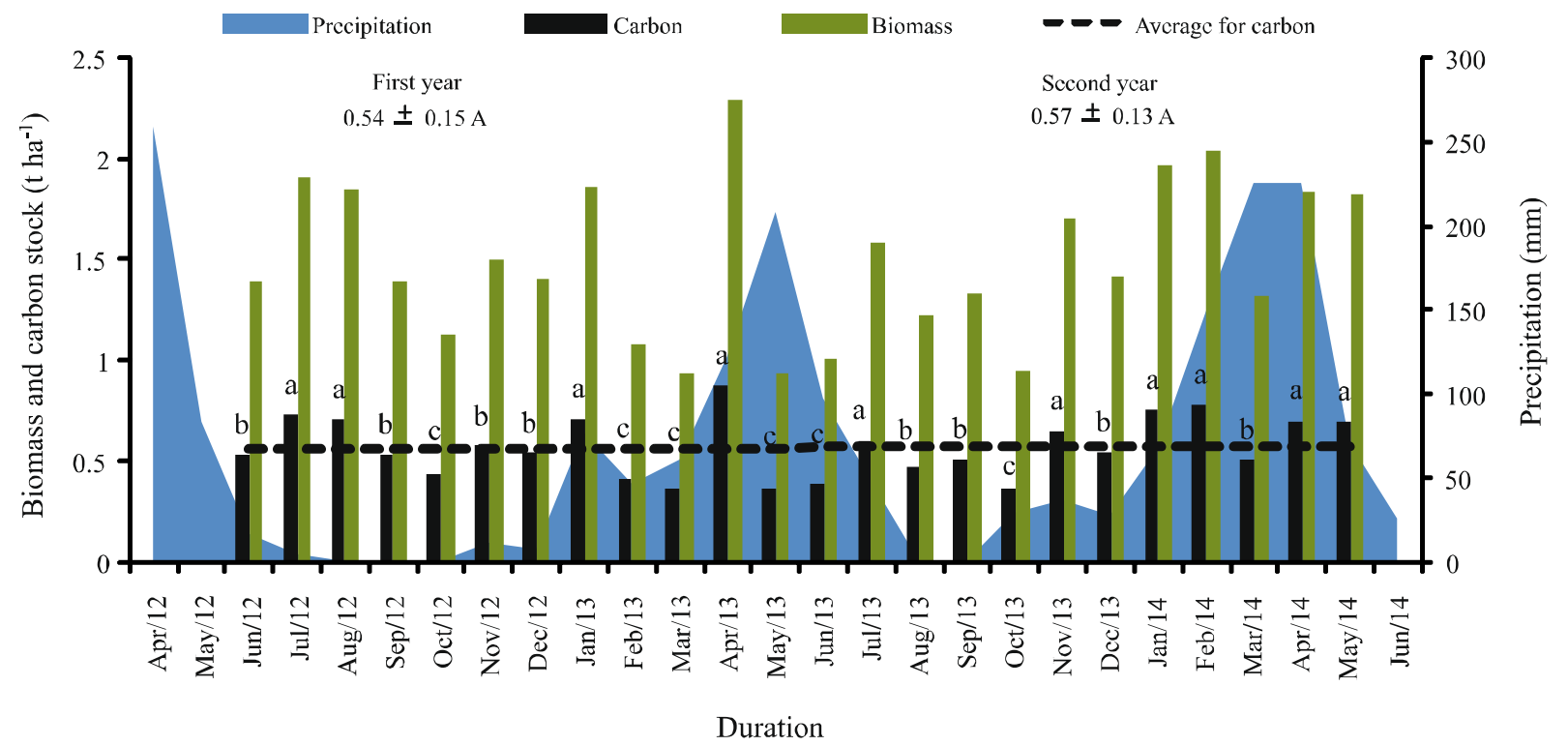


therefore be said that the herbaceous layer of a tropical dry forest contributes to its stock of carbon.

\section{Stocks of carbon in the roots}

Based on the root to shoot ratio, a total of $10.94 \mathrm{t} \mathrm{ha}^{-1}$ of biomass was calculated (Table 4); a similar value was found by Tiessen et al. (1992), who studying a tropical dry forest in Brazil, found values ranging from 8 to $12 \mathrm{t} \mathrm{ha}^{-1}$.

It can also be seen from Table 4 that the small variation in standard deviation for each diameter class being evaluated confirms the representativeness of the samples, and that for those roots located among the trees the greatest accumulation of biomass took place in the dry season (8.96 and 10, $95 \mathrm{tha}^{-1}$ ), however only in the second year of the evaluation (2013) was there a significant difference seen between periods. It is noteworthy that with a time scale of one year it is possible to see changes in the amount of root biomass, mainly influenced by rainfall.

It can also be seen that the thin roots displayed greater biomass during the rainy season, reaching a maximum value of $0.78 \mathrm{t} \mathrm{ha}^{-1}$ in the first year (Table 4); a lower value than that found by Persson and Stadenberg (2009), who found $2.8 \mathrm{t} \mathrm{ha}^{-1}$ when studying a fragment of dry forest in Sweden.

For the total carbon stock in the roots, it was found that there was no significant difference in the first year between the periods under evaluation, however in the second year of the assessment, carbon stocks in the dry season exceeded the rainy season by more than twice (Table 4).

The greater production of fine-root biomass during the rainy season is due to growth so as to better capture water and absorb as much of the resource as possible (Table 4). However, the fact that there was an extended rainy season in the two years under evaluation (seven months of rain in 2012 and nine months in 2013) may also have favoured a greater increase in fine roots; whereas the decrease in fine-root biomass in the dry season may be related to senescence, a strategy used by the plants to reduce energy costs during this period. Konôpka et al. (2006) corroborate this assertion, stating that the increase in temperature and reduction in moisture level lead to this high mortality among the fine roots, with a higher availability of moisture therefore promoting their growth.

For the medium and coarse roots, comparing the dry and rainy seasons, an opposite pattern to that seen with the fine roots can be observed, with more biomass being found in the dry season and less in the rainy season (Table 4). This result is due to the expansion in the diameter of these roots, considering their main function of accumulating reserves (VOGT; BLOOMFIELD, 1991), where reserves are accumulated during the rainy season and maintained during the dry season.

It can further be seen that summing the carbon accumulated in the roots for both periods (dry and rainy),

Table 4 - Biomass and estimates of the carbon stock in the roots of a tropical dry forest

\begin{tabular}{|c|c|c|c|c|c|}
\hline \multicolumn{6}{|c|}{2012} \\
\hline \multirow[t]{3}{*}{ Diameter class $(\mathrm{mm})$} & Layer $(\mathrm{cm})$ & \multicolumn{2}{|c|}{ Biomass $\left(\mathrm{t} \mathrm{ha}^{-1}\right)$} & \multicolumn{2}{|c|}{ Carbon stock $\left(\mathrm{t} \mathrm{C} \mathrm{ha}^{-1}\right)$} \\
\hline & & \multicolumn{4}{|c|}{ Season } \\
\hline & & Dry & Rainy & Dry & Rainy \\
\hline Fine $(\phi<2)$ & & $0.58 \pm 0.01 \mathrm{Bc}$ & $0.78 \pm 0.01 \mathrm{Ac}$ & $0.17 \mathrm{Bc}$ & $0.24 \mathrm{Ac}$ \\
\hline Medium $(2<\phi<10)$ & $0-30$ & $3.56 \pm 0.05 \mathrm{Ab}$ & $2.79 \pm 0.04 \mathrm{Bb}$ & $1.54 \mathrm{Ab}$ & $1.21 \mathrm{Bb}$ \\
\hline Coarse $(\phi>10)$ & & $4.82 \pm 0.05 \mathrm{Aa}$ & $3.94 \pm 0.05 \mathrm{Ba}$ & $2.17 \mathrm{Aa}$ & $1.77 \mathrm{Ba}$ \\
\hline All & $0-30$ & $8.96 \mathrm{~A}$ & $7.51 \mathrm{~A}$ & $3.88 \mathrm{~A}$ & $3.22 \mathrm{~A}$ \\
\hline Root x Shoot & 11.90 & 4.73 & & & \\
\hline \multicolumn{6}{|c|}{2013} \\
\hline & & \multicolumn{4}{|c|}{ Season } \\
\hline & & Dry & Rainy & Dry & Rainy \\
\hline Fine $(\phi<2)$ & & $0.52 \pm 0.01 \mathrm{Bc}$ & $0.67 \pm 0.01 \mathrm{Ac}$ & $0.16 \mathrm{Bc}$ & $0.20 \mathrm{Ac}$ \\
\hline Medium $(2<\phi<10)$ & $0-30$ & $3.26 \pm 0.04 \mathrm{Ab}$ & $1.74 \pm 0.04 \mathrm{Bb}$ & $1.41 \mathrm{Ab}$ & $0.75 \mathrm{Bb}$ \\
\hline Coarse $(\phi>10)$ & & $7.17 \pm 0.05 \mathrm{Aa}$ & $3.23 \pm 0.04 \mathrm{Ba}$ & $3.23 \mathrm{Aa}$ & $1.45 \mathrm{Ba}$ \\
\hline All & $0-30$ & $10.95 \mathrm{~A}$ & $5.64 \mathrm{~B}$ & $4.80 \mathrm{~A}$ & $2.40 \mathrm{~B}$ \\
\hline
\end{tabular}

Mean values followed by the same uppercase letter on a line and lowercase letter in a column do not differ by Tukey's test at $0.01 \%$ probability 
the stock is almost the same for the years evaluated, 7.1 and $7.2 \mathrm{t} \mathrm{C} \mathrm{ha}^{-1}$ for the first and second years respectively. However, the first year shows no significant difference for period (Table 4), this was due to the volume of rain in the wet season of the first year $(990 \mathrm{~mm})$ being higher than in the second year $(661 \mathrm{~mm})$, causing greater root development in the first year and less in the second.

\section{CONCLUSION}

The carbon content of the tropical dry forest under evaluation varies according to the compartment being studied. Among the compartments studied, the trees contributed most to a reduction in global warming by stocking $70.87 \%$ of all the carbon found. Summing the carbon stored in the woody $\left(19.27 \mathrm{t} \mathrm{ha}^{-1}\right)$, litter $\left(2.62 \mathrm{t} \mathrm{ha}^{-1}\right)$, herbaceous-plant $\left(0.57 \mathrm{t} \mathrm{ha}^{-1}\right)$ and root $\left(4.73 \mathrm{t} \mathrm{ha}^{-1}\right)$ components, it can be said that the total carbon stock of a tropical dry forest with 30 years regeneration is around $27,19 \mathrm{t} \mathrm{C} \mathrm{ha}^{-1}$. Accordingly, this shows the contribution of the tropical dry rainforest in effectively decreasing $\mathrm{CO}_{2}$ in the atmosphere.

\section{REFERENCES}

AGUIAR, M. I. et al. Carbon sequestration and nutrient reserves under different land use systems. Revista Árvore, v. 38, p. 81-93, 2014.

ALCOFORADO-FILHO, F. G., SAMPAIO, E. V. S. B.; RODAL, M. J. N. Florística e fitossociologia de um remanescente de vegetação caducifólia espinhosa arbórea em Caruaru, Pernambuco. Acta Botânica Brasílica, v. 17, p. 287-303, 2003.

BRASIL. Ministério do Meio Ambiente. Mapa de cobertura vegetal. Disponível em: <http://www.mma.gov.br/biomas/ caatinga/mapa-de-cobertura-vegetal $>$. Acesso em: 10 mar. 2015.

GLENDAY, J. Carbon storage and emissions offset potential in an African dry forest, the Arabuko-Sokoke Forest, Kenya. Environmental Monitoring \& Assessment, v. 142, p. 8595, 2008 .

IPCC, Climate change 2007: The physical science basis. Genebra: IPCC, 2007. 1.8 p. A report of Working Group I of the Intergovernmental Panel on Climate Change. Assessment Report, 4. Disponível em: 〈http://www.ipcc.ch>. Acesso em: 12 jan. 2014.

KONÔPKA, B. et al. Fine root dynamics in a Japanese cedar (Cryptomeria japonica) plantation throughout the growing season. Forest Ecology and Management, v. 225, p. 278286, 2006.

KOSMAS, C.; DANALATOS, N. G.; GERONTIDIS, S. T. The effect of land parameters on vegetation performance and degree of erosion under Mediterranean conditions. Catena, v. 40, p. 317,2000 .

LOPES, J. F. B. et al. Deposição e decomposição de serrapilheira em área da Caatinga. Revista Agro@mbiente, v. 3, p. 72-79, 2009.

MOHANRAJ, R.; SARAVANAN, J.; DHANAKUMAR, S. Carbon stock in Kolli forests, Eastern Ghats (India) with emphasis on aboveground biomass, litter, woody debris and soils. iForest, v. 4, p. 61-65, 2011.

MOKANY, K.; RAISON, J. R.; PROKUSHKIN, A. S. Critical analysis of root: shoot ratios in terrestrial biomes. Global Change Biology, v. 12, p. 84-96, 2006.

NAVROSKI, M. C. et al. Quantificação de biomassa e comprimento de raízes finas em povoamento de Eucalyptus cloeziana F. Muell. Revista Brasileira de Ciências Agrárias, v. 5 , p. $535-540,2010$.

NGO, K. M. et al. Carbon stocks in primary and secondary tropical forests in Singapore. Forest Ecology and Management, v. 296, p. 81-89, 2013.

PAIVA, A. O.; REZENDE, A. V.; PEREIRA, R. S. Estoque de carbono em cerrado sensu stricto do distrito federal. Revista Árvore, v. 35, p. 527-538, 2011.

PALÁCIO, H. A. de Q. Avaliação emergética de microbacias hidrográficas do semiárido submetidas a diferentes manejos. 2011. 149 f. Tese (Doutorado em Engenharia Agrícola) - Centro de Ciências Agrárias, Universidade Federal do Ceará, Fortaleza, 2011.

PEREIRA JUNIOR, L. R.; ANDRADE, A. P. de.; ARAÚJO, K. D. Composição florística e fitossociológica de um fragmento de caatinga em Monteiro, PB. Revista Holos, v. 28, p. 73-87, 2012.

PERSSON, H.; STADENBERG, I. Spatial distribution of fine-roots in boreal forests in eastern Sweden. Plant Soil, v. 318, p. 1-14, 2009.

REIS, A. M. S. et al. Inter-annual variations in the floristic and population structure of an herbaceous community of "caatinga" vegetation in Pernambuco, Brazil. Revista Brasileira de Botânica, v. 29, p. 497-508, 2006.

REZENDE, A. V. et al. Comparação de modelos matemáticos para estimativa do volume, biomassa e estoque de carbono da vegetação lenhosa de um cerrado sensu stricto em Brasília, DF. Scientia Forestalis, v. 71, p. 65-76, 2006.

SAMPAIO, E. V. S. B.; SILVA, G. C. Biomass equations for brazilian semiarid caatinga plants. Acta Botânica Brasileira, v. 19, p. 935-943, 2005.

SANTANA, J. A. da S. Estrutura fitossociológica, produção de serapilheira e ciclagem de nutrientes em uma área de Caatinga no Seridó do Rio Grande do Norte. 2005. 184 f. Tese (Doutorado em Agronomia) - Centro de Ciências Agrárias, Universidade Federal da Paraíba, Areia, 2005.

SANTANA, J. A. da S.; SOUTO, J. S. Diversidade e estrutura fitossociológica da caatinga na estação ecológica do seridó-RN. 
Revista de Biologia e Ciências da Terra, v. 6, p. 232-242, 2006.

SANTOS, J. C. et al. Caatinga: the scientific negligence experienced by a dry tropical forest. Tropical Conservation Science, v. 4, p. 276-286, 2011.

SKUTSCH, M. M.; LIBASSE, B. Crediting carbon in dry forests: The potential for community forest management in West Africa. Forest Policy and Economics, v. 12, p. 264270, 2010.

SOUTO, P. C. Acumulação e decomposição da serrapilheira e distribuição de organismos edáficos em área de Caatinga na Paraíba, Brasil. 2006. 150 f. Tese (Doutorado em Agronomia)
- Centro de Ciências Agrárias, Universidade Federal da Paraíba, Areia, 2006.

THURNER, M. et al. Carbon stock and density of northern boreal and temperate forests. Global Ecology and Biogeography, v. 23, p. 297-310, 2014.

TIESSEN, H. et al. Carbon Sequestration and Turnover in Semiarid Savannas and Dry Forest. Climatic Change, v. 40, p. $105-117,1998$.

VIEIRA, G. et al. Teores de carbono em espécies vegetais da caatinga e do cerrado. Revista Acadêmica Ciências Agrárias e Ambientais, v. 7, p. 145-155, 2009.

VOGT, K. A.; BLOOMFIELD, J. Plant roots: the hidden half. 3. ed. New York: Marcel Dekker, 1991. 1146 p. 